\title{
Government Bailout of Distressed States in Nigeria: An Analysis of the 2015 Fiscal Crisis
}

\author{
Festus Fatai, ADEDOYIN ${ }^{1 *}$ Abel, FUMEY ${ }^{2}$ Abiodun, POPOOLA ${ }^{3}$ \\ 1. PhD Candidate, Faculty of Management, Bournemouth University, Talbot, U.K. \\ 2. Lecturer, Department of Economics, University of Ghana \\ 3. Senior Lecturer, Department of Economics, Ahmadu Bello University, Zaria \\ * Email: s5076568@bournemouth.ac.uk
}

\begin{abstract}
This study is aimed at determining the benefits or otherwise of the bailout made to states by the federal government of Nigeria. It sought to answer the questions of whether the bailout was a reward to inefficiency and/or depleted the federal government revenue base without any potential benefits; if it followed any prudent public policy principles in Nigeria or not; and extent to which the bailout package has resolve the state fiscal crisis and its effect on state governments' internal revenue bases. With data sourced from the Central Bank of Nigeria, Federal Ministry of Finance, and other sources, content analysis was employed which led to the computation of the fiscal sustainability index of each of the states of the federation. Based on the sustainability index, the interpolation of financial data of government revenue revealed that a gap between revenue and expenditure should not be immediately fed by debt, especially where there are other sources of revenue available to state governments. Hence, when a state is still fiscally sustainable, an option of debt is not practicable. A conclusion of the study is that ethically, problem solving via bailout funds may be costlier than estimated benefits.
\end{abstract}

Keywords: Government bailout, Fiscal Crisis, Fiscal Sustainability Index, Internally Generated Revenue, Monthly Statutory Allocation.

\section{Introduction}

Recent developments in the global economy since 2015, particularly in the crude oil market have affected the fiscal operations of many countries including Nigeria. Some of the major events include the disagreement between the Organization of Petroleum Exporting Countries (OPEC) member countries on production levels, and Non-OPEC countries' unwillingness to cut down on production. In addition, the Iran's nuclear deal which is capable of bringing about 1 million barrel per day (bpd) and its bid to reach its pre-sanction level of $4 \mathrm{million}$ bpd, have had its toll on several developing economies. The overall effect has been negative as shown by the economic outlook for 2016 in many countries. Other global developments aside crude oil includes the increase in interest rate by the US Federal Reserve by 25 basis points (bps), the recent slowdown in the Chinese economy, increased migration into Europe and the drive for reduced emissions in both developed and developing countries to safe levels by the United Nations.

The effects of those events on Nigeria's economy cannot be overemphasized as the economy depends quite heavily on crude oil. As such, with such low oil prices around $\$ 40$ per barrel as at December 2015, its attendant effect on the revenue of the country and the forecast for 2016 and beyond seem poor. This may lead to the witnessing of persistent fall in federal government revenue, hence, a decline in Monthly Statutory Allocations to State Governments. These results in a problem of tight fiscal stance coupled with a fall in the capacity of states to generate revenue to meet their expenditures.

In a tight fiscal posture, there is a need to understand the relationships among levels of government. According to Richard (1959), when considering the division of governmental functions and financial relations among levels of government in the context of fiscal federalism, it is important to highlight the capacity of each levels of government in terms of their fiscal responsibility. Economic stability and just distribution of income can thus be done by the federal government because of its flexibility in dealing with these problems. Also, because states and localities are not equal in their income, federal government intervention is needed. This is because the welfare of the citizenry becomes important when state failure looms and salary and pension arrears especially are not paid. 
Furthermore, if resources are well disbursed to the lower levels of government, then it is expected that these lower level governments are responsible and fulfill their obligations as at when due. As opined by Oates, 1999, understanding which functions and instruments are best centralized and which are best placed in the sphere of decentralized levels of government are what fiscal federalism entails. Thus, when responsibilities are decentralized among levels or tiers of government, certain benefits are anticipated, such as handling regional and local differences; lower planning and administrative costs; competition among local governments which include the citizens so as to encourage political innovations among others.

Despite these benefits however, a weak system of fiscal federalism can suffer from the use of unskilled public officers by state and local governments; migration of citizens from regions with bad fiscal system to regions with good fiscal system (as is the case of Lagos state, Rivers state among others in Nigeria). Other effects are lack of unaccountability of state and local governments to constituents; desire for complete independence of the local governments from the national government. These disadvantages arise from an improperly managed fiscal federal system and therefore require that lower level governments be assisted or 'bailed-out' in times of financial crisis or financial distress. A bailout otherwise known as financial rescue generally involves an intervention by a person or company to help another person or company out of financial difficulties. It can be described as an informal term for extending the arm of support in the form of a financial assistance to a company or a country or a lower level government, which is challenged by financial difficulty or even bankruptcy ${ }^{1}$. A bailout can, but does not necessarily, avoid an insolvency process.

A government bailout usually involves the government paying or lending money to save a company or industry from failing. For example, the 2008 bailout of the failing auto industry in the United States involved a large corporation that is pivotal to the wellbeing of her economy. For such big corporations, the central bank calculates the impact on the economy, because if such a big industry goes out of business then thousands of people will lose their jobs and the implications of that will be huge on the economy. So, if the federal government thinks that by helping the states with salary intervention fund can make it come out of a fiscal crisis then may be it is better for the government to support these states. However, the bone of contention hovers around how effectively the different tiers of government use their existing resources to perform their expected functions and how much bailout is necessary in a time of financial distress as well as, the guarantee that once they are bailed-out, they would be completely free from distress. This enquiry is important from the standpoint of the reasons that have been identified as the core causes of fiscal distress. This thus necessitates a central government bailout, in which financial assistance by the government is provided to the states that appeared to be on the brink of collapse. The belief is that without this aid, the fiscal crisis would create rippling effects throughout the economy.

This study aims at examining the nature, trends and bases of bailout in Nigeria in view of the 2015 fiscal crises, and in comparison, with other countries. It also seeks to analyze the effects of state bailout on sectoral and aggregate economic performance in Nigeria. The significance of this enquiry is to present ways through which Nigeria can use bailouts to enhance better management of the risks induced by the fiscal crisis; and how bailout fund as an economic policy programme can provide real social welfare benefits to citizens and not cost.

The study is organized into six sections. Following the introductory section is section two which discusses the nature and causes of the Nigeria's fiscal crises, and the bailout process, while section three focuses on the literature review, which discusses the theoretical bases, and some conceptual issues of bailout as well as bailouts and soft budgeting constraints. Section four provides the analytical techniques and the data whereas section five reports the results and discusses the findings, and section six presents conclusions and lessons for policy.

\section{Nigeria's Fiscal Crisis: Nature and Causes}

The fiscal crisis in Nigeria cannot be separated from the recent global happenings as it contributed to the increase supply of crude oil in the global oil market, which led to the falling global prices that ignited the crisis. This is because, the falling prices led to expected revenue falls without commensurate expenditure falls creating a mismatch. It is in light of this that State governments in Nigeria were confronted with challenges of fiscal crisis, due to dwindling oil revenue of the government. This has thus, caused structural changes in the fiscal landscape of Nigeria over the recent periods and has caused fluctuations in both revenue and expenditure over the business cycle of the economy.

\footnotetext{
${ }^{1}$ www.afarber.com/definition-of-bailout
} 
Numerous factors are at work in a fiscal crisis such as those, which affects state governments, but the key one is the State's over dependence on revenue distributed by the federal government. This is because the excessive reliance on these federal transfers limited the efforts at raising State's internally generated revenue (IGR). Since the states' internal revenue was low coupled with reduced federal grants, to meet up with their financial obligations, the state governments resorted to short-term borrowing from financial institutions. As this situation progressed over time, the states' indebtedness to the financial institutions increased which rendered most of them to be vulnerable and lowered their credit worthiness status. As a result, chances of borrowing from the financial institutions became extremely slim, hence their inability to honour both statutory and discretionary payments.

In June 2015, the sub-national debt profile was estimated at $\$ 3.3$ billion excluding domestic debt stocks. In view of this, state governments were heavily indebted and constraint with low levels of internally generated revenue (IGR). As a result, the state governments called for a financial bailout from the Federal Government to avert the consequent economic distortions and growth changes. Another factor that led to the internal revenue shortage is the mismanagement of the proceeds as it lacks accountability and transparency. It is reported that in 2014 and 13 states were not regular with the remission of their IGR to the Federal government. This posed a weak economic outlook for the year 2015 which led to the states' fiscal crisis. The states involved include Abia, Adamawa, Borno and Cross River. Others are Ebonyi, Edo, Gombe and Jigawa. The rest are Kano, Kwara, Ondo, Taraba and Yobe. Accordingly, the National Bureau of Statistics provides that of these 13 states Ebonyi and Jigawa have not reported since 2012 and for Abia, since 2013 while nine others did not report as at June 2015. In addition, 19 states reported an average IGR below N10 million in 2014, which depicts an under-performance. This is shown in figure 1 while similar case of 22 states is reported in 2015 and is shown in figure 2.

Figure 1: States Internally Generated Revenue, 2014 (below N10billion)

\section{States' IGR N'billion}

u2014 IGR N'bilion

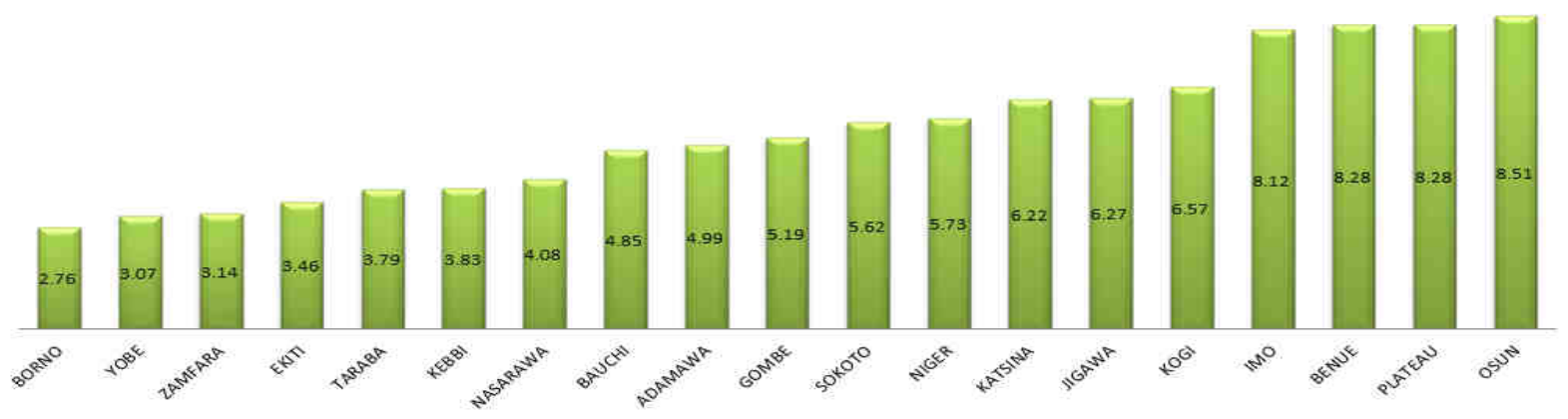

Figure 2: States Internally Generated Revenue, 2015(below N10billion)

\section{States' IGR (N'billion)}

II 2015 IGR (N'billion)

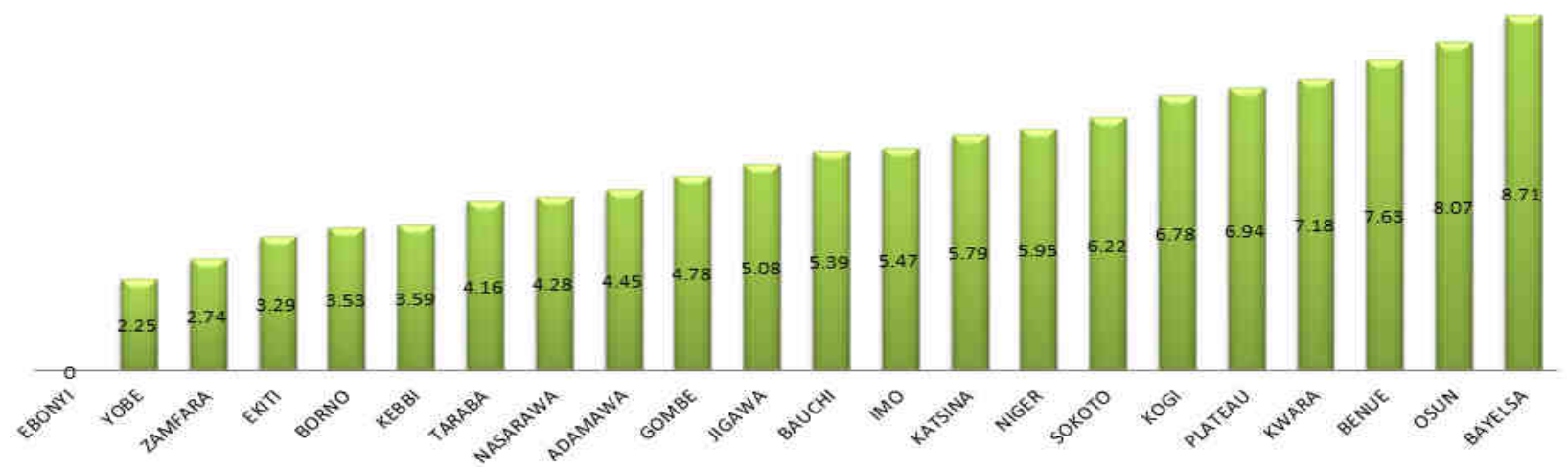

It is not clear how these things are allowed to happen within the overall fiscal scheme of the country. The inability of these states to be consistent and transparent in their internal revenue generation and management can 
only lead to adverse consequences on their inhabitants in terms of welfare. Note that the prolonged non-payment of salaries to workers reduces the financial capacity of households and their consumption patterns. Economic theory predicts that when consumption expenditure fails, there would be a negative effect on consumer and industrial goods sectors, and these two sectors constitutes about 56.3\% to market capitalization in Nigeria.

Note that not all the states performed abysmally in raising their internal revenue. Figure 3, shows that in 2014, about 17 states generated above N10 billion each with Lagos state leading the chart with N276.16 billion. In 2015, figure 4 shows that 14 states had average IGR above n10 billion with Lagos generating N268.22 billion which reveals a reduced amount compared to N276.16 billion generated in 2014. There was a general decline in IGR in 2015 as compared to 2014. The decline in the state's ability to generate revenue internally was attributed to the global down turn in crude oil prices which badly affected all sectors of the Nigerian economy.

Figure 3: States Internally Generated Revenue, 2014(N10billion and above)

\section{IGR N'billion}
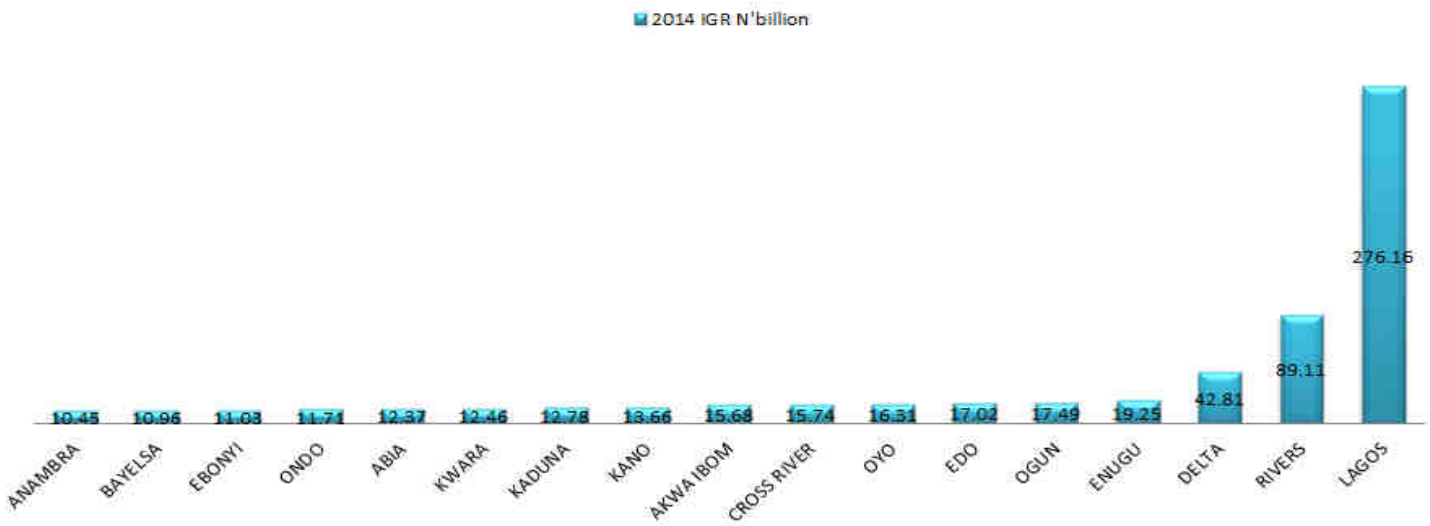

Figure 4: States Internally Generated Revenue, 2015 (N10billion and above)

\section{IGR (N'billion)}

U. 2015 IGR (N'billion)

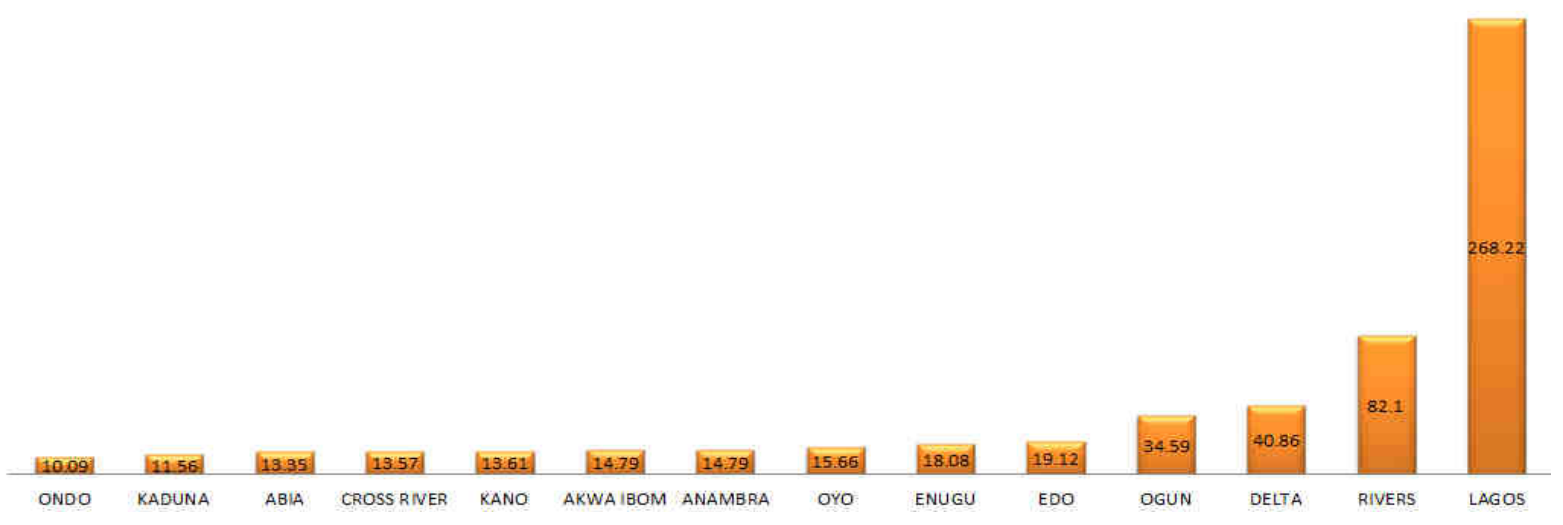

Unlike the Federal Government who has the capacity to borrow more freely from the capital market in order to meet its recurrent expenditure especially during a global crisis. State and local governments do not have such laxity to do same. These lower level governments therefore bare high debt burden, thereby wallowing in a fiscal crisis given their weak capacity to generate revenue internally. In sum, not all the state governments in Nigeria were caught up in the 2015 Fiscal Crisis web, which means certain internal rigidities, existed within the affected states. The possible causes include poor bookkeeping, negligence on the part of the state governing bodies and issues of transparency in the management of public finance, which have great implications for any socioeconomic development and over-dependency on the central government. 


\section{$2.1 \quad$ The Bailout Process}

According to the Debt Management Office (DMO), the government has attached high priority to addressing the fiscal imbalance faced by the states in the Federation. In their assessment,

Due to over $43 \%$ fall in international crude oil prices and a drop of revenue allocation of about $40 \%$ to the states has rendered them fiscally irresponsible to their people, so the Federal Government has no option than to come to the aid of the states for a short term fiscal stabilization. As a result, DMO proposed a restructuring of state governments' loans into Federal Government bonds. This is expected to reduce the debt-service outflow and thus help states to meet up with outstanding payments of salaries and pensions. In order for states to access the bailout package, certain conditions must be fulfilled. The first condition is that the states are expected to apply for the programme, and in this instance, twenty-three (23) states requested for the restructuring of the bank loans into FGN bonds, which was done in two phases. Eleven (11) states made up the first phase, which submitted the necessary and duly completed documentations together with their bank balances as at August 14, 2015. When these conditions were satisfied, their bank loans were restructured into a 20-year FGN bond with effective date of August 17, 2015. The remaining twelve (12) states were considered in the second phase and their loans were accordingly restructured, effective September 16, 2015.

The banks involved in Phase I were fourteen (14) and their total loans to the eleven States, which were restructured amounted to N322.788 billion. Twelve (12) banks were involved in Phase II of the restructuring operation and the total loans restructured was N252.728 billion, bringing the total restructured amount for the twenty-three States to N575.516 billion. The restructuring was operative using a re-opening of the FGN Bond issued on July 18, 2014 and maturing on July 18, 2034. The pricing was based on the yield to date of the bond at a 30-day average, resulting in a transaction yield of $14.83 \%$. Indicators of the impact of the debt management operations included a monthly debt service burden, which dropped between $55 \%$ and $97 \%$, among the twentythree States, and an interest rate savings between 3\% to 9\% per annum (DMO, 2015).

It is expected that the debt restructuring will improve the balance sheet of the banks involved as the weak loan assets of the states would be replaced with the FGN bonds which are high quality sovereign assets. These bonds are traded on the secondary market and could be of immense benefit to other sectors of the economy when traded, since bank loans are now made available to private firms. The debt service burden of states will also reduce and help to achieve fiscal balance by states. In summary, the commercial loan-to-FGN Bond plan was one of the helpful options for short-term fiscal stabilization, which was put forward by the DMO to reduce the debt-service outflow of states and free resources for them to meet other obligations, particularly clearance of arrears of salaries and pensions.

\section{Literature Review}

\subsection{Theoretical Literature}

The theoretical base of this study is the too-big-to-fail theory, which was propounded by Stewart McKinney in 1984. The "too big to fail" theory asserts that certain corporations, and particularly financial institutions, are so large and so interconnected that their failure would be disastrous to the greater economic system, and that they therefore must be supported by government when they face potential failure. ' $T o o$ big to fail' may refer not only to the scale of the activity of the specific financial institution. It also takes into consideration both the public and economic aspects of the whole economy. State aid is nothing but taxpayers' money. When the state decides to rescue a bank, it is de facto weighing the social and economic consequences of such an action. In the case of the too big to fail dilemma, it might be more profitable to invest public resources in saving the institution than to allow it to fail. Big failures can even lead to riots. They diminish the reputation of the state and weaken the economy. The consolidation and globalization processes were bringing a lot of benefits of scale for the financial sector institutions. The profitability advantage was additionally strengthened by the arguments that this process is risk lowering.

Proponents of this theory also believe that some institutions are so important that they should become recipients of beneficial financial and economic policies from governments or central banks. ${ }^{3}$ Some economists such as Paul Krugman hold that economies of scale in banks and in other businesses are worth preserving, so long as they are

\footnotetext{
2 "Too Big to Fail, Too Blind to See". www.ssrn.com

3 "What is too big to fail? definition and meaning". Businessdictionary.com. Retrieved 2013-04-27.
} 
well regulated in proportion to their economic clout, and therefore that "too big to fail" status can be acceptable. The global economic system must also deal with sovereign states being too big to fail. ${ }^{45}$ The too big to fail theory argues that big size should increase the stability by higher resistance to the shocks. In other words, a big state in Nigeria such as Lagos State, Rivers State or Kano state should not default, since the theory assumes that they possess the size (economic and political size) needed to withstand a shock. However, a lump-up of states, considers a default as an aftermath of internal structural imbalances that became inevitable thereby leading to a crisis. Also, additionally, higher products range and regional diversification should create negative correlations that diminish sensitivity to local volatilities and lack of synchronization in business cycles. In the times of crisis, this way of thinking turned out to be wrong. Huge financial institutions changed their role from market players to market makers. They became the market. As a result, they accumulated a large systemic risk.

The conclusion is that growing the size should cause increased responsibility. It should be especially visible in the costs of activity. States in Nigeria that engage in projects should consider cost implications and revenue concerns so as to avoid largely been negatively affected in times of distress.

\subsection{Conceptual Literature}

In a tight fiscal posture, there is a need to understand the relationships among levels of government. Richard (1959) advanced the notion that it is important to highlight the capacity of each levels of government in terms of their fiscal responsibility when the division of governmental functions and financial relations among levels of government in the context of fiscal federalism is being considered. Economic stability and just distribution of income can thus be done by the federal government because of its flexibility in dealing with these problems. Also, because states and localities are not equal in their income, federal government intervention is needed. This is because the welfare of the citizenry becomes important when state failure looms and salary and pension arrears especially are not paid. Furthermore, if resources are well disbursed to the lower levels of government, then it is expected that these lower level governments are responsible and fulfill their obligations as at when due. As opined by Oates, 1999, "understanding which functions and instruments are best centralized and which are best placed in the sphere of decentralized levels of government" is what fiscal federalism entails. Thus, when responsibilities are decentralized among levels or tiers of government, certain benefits are anticipated, such as handling regional and local differences; lower planning and administrative costs; competition among local governments which include the citizens so as to encourage political innovations among others.

Despite these benefits however, a weak system of fiscal federalism can suffer from the use of unskilled public officers by state and local governments; migration of citizens from regions with bad fiscal system to regions with good fiscal system (as is the case of Lagos state, Rivers state among others in Nigeria). Other effects are lack of unaccountability of state and local governments to constituents; desire for complete independence of the local governments from the national government. These disadvantages arise from an improperly managed fiscal federal system and therefore require that lower level governments be assisted or 'bailed-out' in times of financial crisis or financial distress. In Nigeria, government is decentralized into federal, states and local governments for ease of administration and sends development to every corner of the country, so there are levels of government. This is usually expected to help government meet up with its tasks at federal, state and local government levels. Other countries in recent times have also been decentralized. Decentralization has been promoted based on different arguments: democracy and good governance; preservation of cultural and ethnic identity; and economic rationales (Rodríguez-Pose and Sandall 2008; Kwon 2013). This decentralization of government responsibilities poses the threat of a common pool problem; a situation in which the lower level government avoids part of its responsibilities and shifts the burden of providing public services to the central government.

\subsection{Bailouts and Soft Budget Constraints}

Shifting of responsibilities by subnational governments leads a reliance or dependence on the central governments in what is referred to as soft budget constraint. According to Kornai (1980), when a subnational government faces a soft budget constraint, it expects a higher-level government to support it in the case of financial distress. The justification of such expectation may remain unclear; however, it could be based on formal institutions or regulations, or on informal practices. A soft budget constraint creates a platform for lower level government to engage themselves in increased risk taking and excessive borrowing leading to inefficient allocation of scarce resources. This presupposes that the lower level governments may misappropriate and hide under the principle to call for support from the central government.

\footnotetext{
${ }^{4}$ Paul Krugman "Stop Too Big to Fail'." New York Times, April 21, 2010

${ }^{5}$ Paul Krugman "Too big to fail", New York Times, June 18, 2009
} 
It is expected in this regard that the central government should establish strict regulations that could help curtail lower level government's level of deficits or borrowing, thereby averting a form of fiscal crisis as is the case in Nigeria. This may warrant a constraint on deficits or on borrowing with measures to eradicate loopholes in the policy. Evidence from the recent European sovereign debt crisis illustrates that this is true for national or federal governments as well. Based on the principles of soft budgeting constraints, it is evident that bailout seems inevitable, particularly when lower level governments are in fiscal crisis because provision of basic social amenities are indispensable (see, Dewatripont and Maskin 1995; Goodspeed 2002; Kornai et al. 2003; Rodden 2006). In Nigeria, no specific guideline or policy exists to guide the conduct of bailout, as it exists in other countries. For instance, Dutch law explicitly states that lower levels of government, which are no longer able to balance their books, may apply for a bailout, and this bailout takes the form of a gift and not a loan. In this situation, an occurrence of bailout, which is solved by this approach, is sustainable. This is because few Dutch municipalities need to be bailed out, and the total amount spent on bailouts is modest. After the bailout, municipalities tend to improve their financial situation quite rapidly which does not call for later bailout. The bailout system does not appear to give municipalities a strong incentive to misbehave, thereby minimizing the moral hazard effects.

\section{Analytical Technique and Data}

\subsection{Analytical Technique}

This study is basically historical and the research design is predominantly descriptive in nature. The analysis is mainly qualitative with the use of secondary data on fiscal stance of Nigeria which are presented in tables, charts and graphs using Microsoft Excel programme. It focuses on states affected by the fiscal crisis, their debt profiles and levels of IGR for the periods of 2014 and 2015. It also looks at the amount of bailout that each state applied for, amount of debt restructured and the bailout amount finally approved by the Federal Government. The charts and graphs are used to quantify and interpolate the internally generated revenue (IGR) of states, their monthly allocations, magnitude of state debts, comparison of debts level to fund, amount of salary intervention fund disbursed, current basic macroeconomic variable behaviour amongst others.

\subsection{Data Sources}

This study considers the states affected by the fiscal crisis, their debt profile and levels of IGR for the periods 2014 to 2015, as well as the amount of bailout applied for, amount of debt restructured and amount of bailout finally approved by the Federal Government. The analysis focuses on secondary data which are sourced from the CBN official website on monthly economic reports. Other sources include the Ministry of Finance, Office of the Accountant-General of the Federation, National Bureau of Statistics and Debt Management Office (DMO) Official Newsletter. The data on IGR is sourced from National Bureau of Statistics Quarterly data survey, while the average monthly Revenue, Capital and Recurrent Expenditure of states is sourced from the monthly report of the office of the accountant general. States Debt ranking and debt restructuring are sourced from DMO's official bulletin.

\section{Results and Discussions}

\subsection{Macroeconomic Stance during the Crisis}

Given the fiscal crisis that confronts the economy, it is imperative to underscore the behaviour of certain key macroeconomic variables and their overall impact on the condition. This assessment is necessary because when aggregate demand is adversely affected, investors' confidences, output growth exchange rate, balance of payments condition, among other variables are all affected.

As shown in Table 1 and figure 5 using quarterly data, 2015 showed that there was an increase in broad money supply and this continued and even accelerated in the fourth quarter. This key monetary aggregate recorded a growth of 7.0percent in the last quarter of 2015, which marked the period when the salary intervention fund was dispatched to the state government. In other words, we can attribute this development grossly, to the 11.2 and 8.2 per cent increase in the net foreign assets and other assets (net) of the banking system, respectively. There was a reduction in the deposit and lending rates of banks during the fourth quarter of 2015. The falling trends of basic market indicators also affected the Nigerian Stock Exchange (NSE). The value of money market assets owing at the last quarter of 2015 was N8, 615.72 billion, representing a fall of 4.6 per cent below the previous level. 
Table 1: Macroeconomic Data: December 2014 - November 2015

\begin{tabular}{|c|c|c|c|c|c|c|c|c|c|c|c|c|}
\cline { 2 - 13 } \multicolumn{1}{c|}{} & Dec-14 & Jan-15 & Feb-15 & Mar-15 & Apr-15 & May-15 & Jun-15 & Jul-15 & Aug-15 & Sep-15 & 0tt-15 & Nov-15 \\
\hline —Exchange Rate & 188.45 & 181.78 & 194.48 & 197.07 & 197 & 197 & 196.92 & 196.97 & 197 & 197 & 196.99 & 196.99 \\
\hline — Crude Oil Price & 110.19 & 48.81 & 58.09 & 56.69 & 57.45 & 65.08 & 62.06 & 57.01 & 47.09 & 48.08 & 48.86 & 44.82 \\
\hline - Inflation Rate & 8 & 8.1 & 8.1 & 8.2 & 8.2 & 8.3 & 8.4 & 8.5 & 8.6 & 8.7 & 8.76 & 8.88 \\
\hline - Interbank Rate & 23.25 & 8.02 & 19.78 & 13.5 & 23.73 & 10.63 & 11.25 & 8.78 & 29.47 & 8.66 & 3.13 & 0.9 \\
\hline
\end{tabular}

Figure 6 5: Macroeconomic Variables' Behaviour between 2014 and 2015

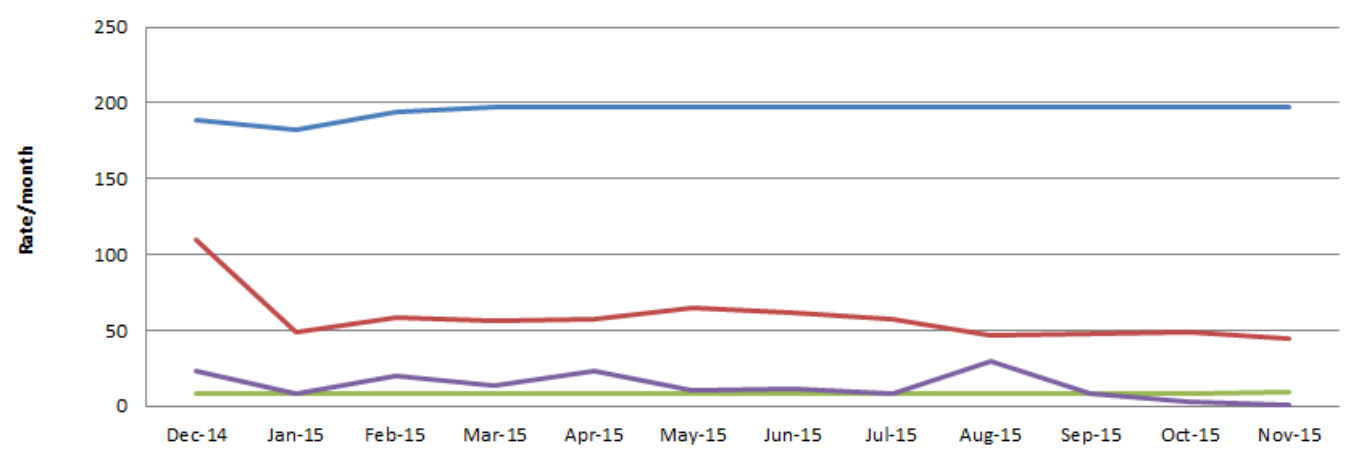

The Federal Government's revenue also reduced by 34.5percent, which is at N1, 600.96 billion as contrasted against her budget estimate. Nigeria's gross oil receipt stood at N830.81 billion and was lower than the expectations designed in the provisional quarterly budget of the government. This was attributed to continuous decline in receipts from crude oil/gas export related to incessant fall in global crude oil price. Apart from the oil receipt, the non-oil receipts also fell below the budget estimate at N770.16 billion. Comparing revenue and expenditure, the Federal Government's reserved revenue was N818.39 billion, while her total expenditure was N1, 107.51 billion, which yields a deficit of N289.12 billion in the last quarter of 2015, which thus yielded a shortfall of N28.87billion in deficit.

Moreover, the end-period headline inflation rate on year-on-year basis was 9.6 per cent, while the inflation rate on a 12-month moving average basis was 9.0 per cent. The level of demand and supply of crude interactions globally was estimated at between 93.95 million barrels per day (mbd) and $95.12 \mathrm{mbd}$, respectively, in the last quarter. Due to the Nigeria's crude oil production capacity and techniques, the mean price of Nigeria's reference crude, that is the Bonny Light (370 API), declined by 13.8 per cent which was below the level in the previous quarter. A comparison between Nigeria's foreign exchange inflow and outflow through the official of the government (i.e. the CBN) was US\$7.14 billion and US\$7.76 billion, respectively, which resulted in a net outflow of US\$0.62 billion. On the average, the exchange rate of the naira vis-à-vis the US dollar at the interbank stood at N196.99, but was N238.69 per US dollar in the parallel market representing a depreciation of 5.7 per cent. These were not without the activities in the international scene, which included fall in oil prices, increase in dollar value, dwindling economic activity in China, fluctuating investor confidence in Europe amongst others.

Given the above analysis of Nigeria's macroeconomic stance in 2015 during the fiscal crisis, it is clear to assert that overall macroeconomic environment remained fragile. This is because the wheels of the economy continually slowed down into the New Year 2016. There was a severe strain on the growth rate of the economy due to fall in both private and public expenditures (decline in aggregate demand) largely caused by the impact of non-payment of salaries at the state and local government levels. This further informed the rate of year-on-year headline inflation upward as well as intense pressure in the foreign exchange market. In the banking sector, the performance of the indicators was very poor. This stemmed from the liquidity withdrawals due to the application of the Treasury Single Account (TSA), the extension of the tenancy of state government loans, and the loans, to the oil and gas sectors. These ultimately impaired their financial intermediation roles, adversely affected economic growth and worsened conditions in the markets.

\footnotetext{
${ }^{6}$ Authors' computation
} 


\subsection{Fiscal Stance of the States: Recurrent and Capital Expenditure}

The recurrent expenditure of states includes personnel costs and overheads. Figures 6 and 7 show the recurrent expenditure of states with expenditure below $\$ 60$ bil and above $\$ 60$ bil respectively. 18 states spent less than \#60billion on salaries, emoluments and overhead costs while 18 states spent above 60 billion. Katsina spent the least amount estimated at $\$ 32$.29billion while Lagos spent the highest with 241.97 billion.
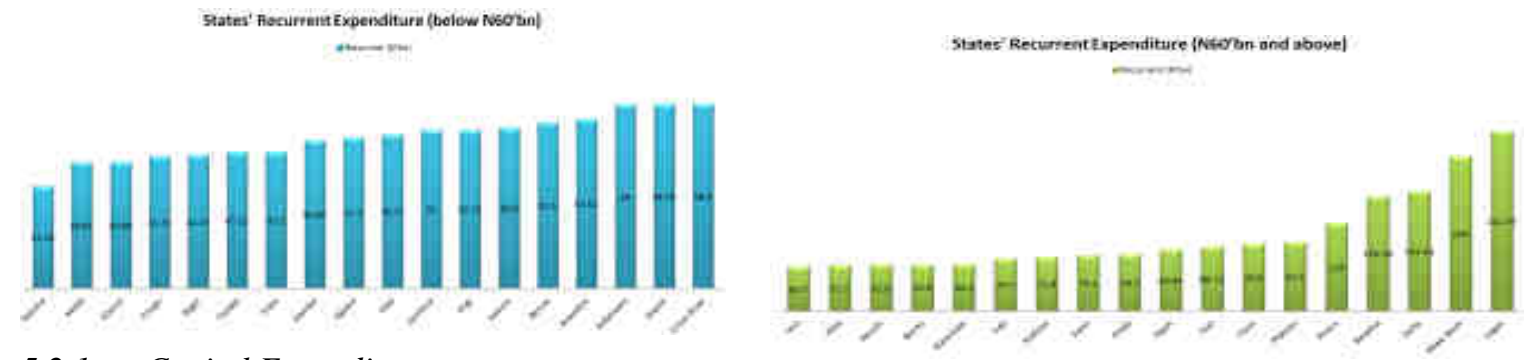

\subsubsection{Capital Expenditure}

Capital Expenditure includes expenses on developmental spending and capital projects. Usually, funds needed to finance capital expenditure by states are driven primarily by bank loans and other associated debts at unsustainable lending rates. From figures 8 and 9, nineteen (19) states have capital expenditure below N80billion while 17 states have it above N80billion Ekiti state had the lowest at N32.23billion while Akwa-Ibom State had the largest amount of capital expenditure at N253billion.

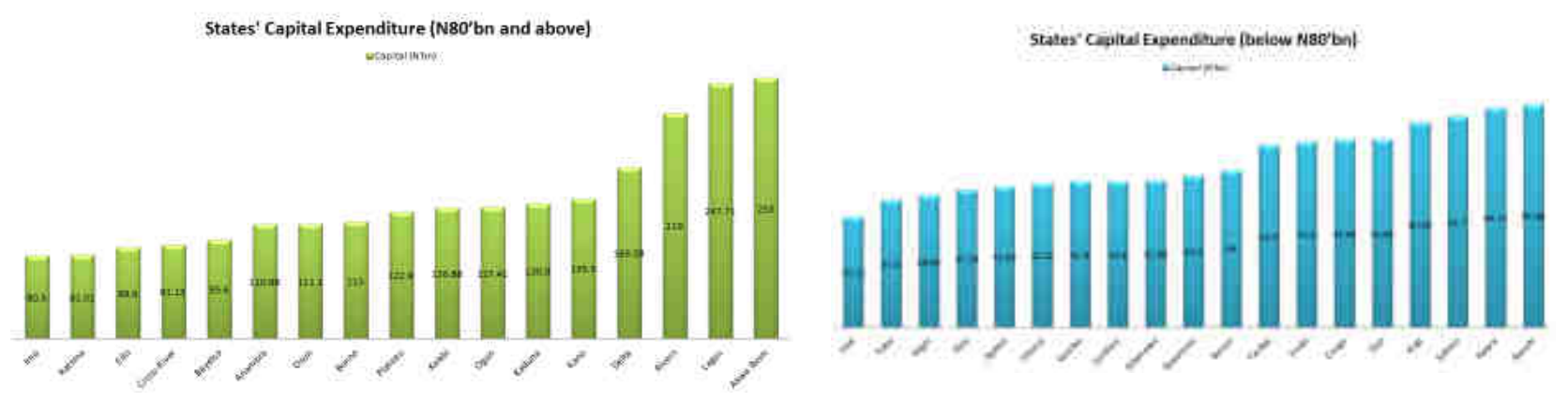

\subsubsection{Average Monthly Shortfall}

In an ideal situation, revenue should equal expenditure. However, this is not usually the case for state governments in Nigeria. Figure 10 shows the identified gaps referred to as shortfalls for each state i.e. the Average Monthly commitment of 18 states having a shortfall when compared to their revenue.

Figure 10: States with Average Shortfall (Revenue-Expenditure Gap)

\section{Average Monthly Residual Revenue After meeting Recurrent Expenditure (Shortfall) N}

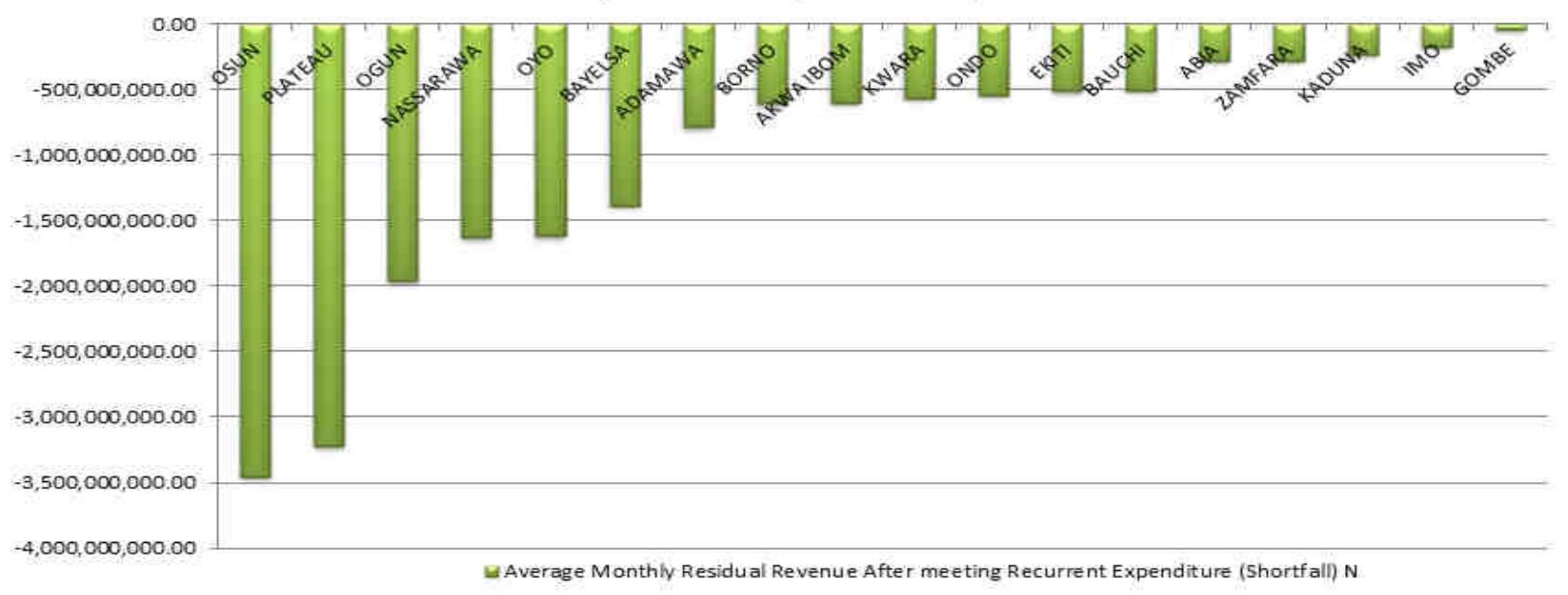


Osun state has the highest amount of shortfall in monthly commitment i.e. salary and pension arrears with about N3.5billion. Plateau, Ogun, Nasarrawa, Oyo follows this and Bayelsa states who also have high amount of shortfall (i.e. inability to meet up with their monthly commitment each month). This could thus prompt the need for debt financing. However, debt financing has been identified as a means of meeting basic capital requirements of the states and not necessarily salary and pension arrears. Thus, not all states with identified shortfall as above are expected to opt for debt financing. Figure 6 shows the debts of states.

\subsubsection{State Governments' Debts}

From figure 11 and 12, Yobe state has the least amount of debt at N7.8billion while Lagos state has the highest amount of debt, which stood at N500.8billion.
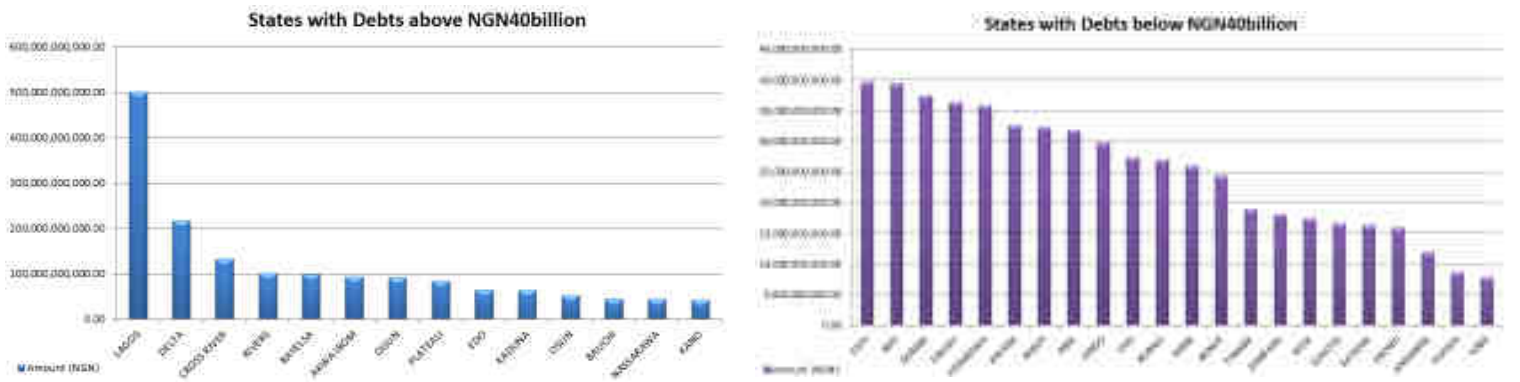

Figure 11: States with Debts > \#40billion Figure 12: States with Debts

\subsection{States' Fiscal Sustainability Index}

In order to further comprehend whether the bailout package encouraged inefficiency and/or depleted the federal government revenue base without any potential benefits and how it has helped resolve the state fiscal crisis, this research analyses the fiscal sustainability index of each state. This interpolation of financial data of government revenue, debt, and expenditure is necessary as it informs the basis for which bailout were given. It also enriches the policy recommendations and conclusions in subsequent subsections of this research. This is because it revealed that a gap between revenue and expenditure should not be immediately fed by debt, especially where there are other sources of revenue available to state governments. Hence, when a state is still fiscally sustainable, an option of debt is not viable. The sustainability index is an interaction index that ultimately considers the overall revenue base of each state during the fiscal crisis, its expenditure profile and total debt stock.

The study employs the following fiscal sustainability index measure as used by BudgIT of States $(2015)^{7}$. The indices are defined as:

Index $A=$ Recurrent Expenditure / IGR+Derivation+VAT

Index B = Recurrent Expenditure / Total Revenue

Index $\mathrm{C}=$ Total Debt Stock / Total Revenue

Sustainability Index $=($ Index A x 35) $+($ Index B x 50) $+($ Index C x 15)

Scores $=100 /$ Sustainability Index

\footnotetext{
${ }^{7}$ BudgIT Policy Document, 2015. Available at www.yourbudgit.com
} 
The formula above is used to compute the sustainability index of all the states in Nigeria, and the summary of the indices is reported in Table 2 with the amount of the bailout fund applied for and the amount disbursed to the state governments. Figure 13 is also derived from Table 2.

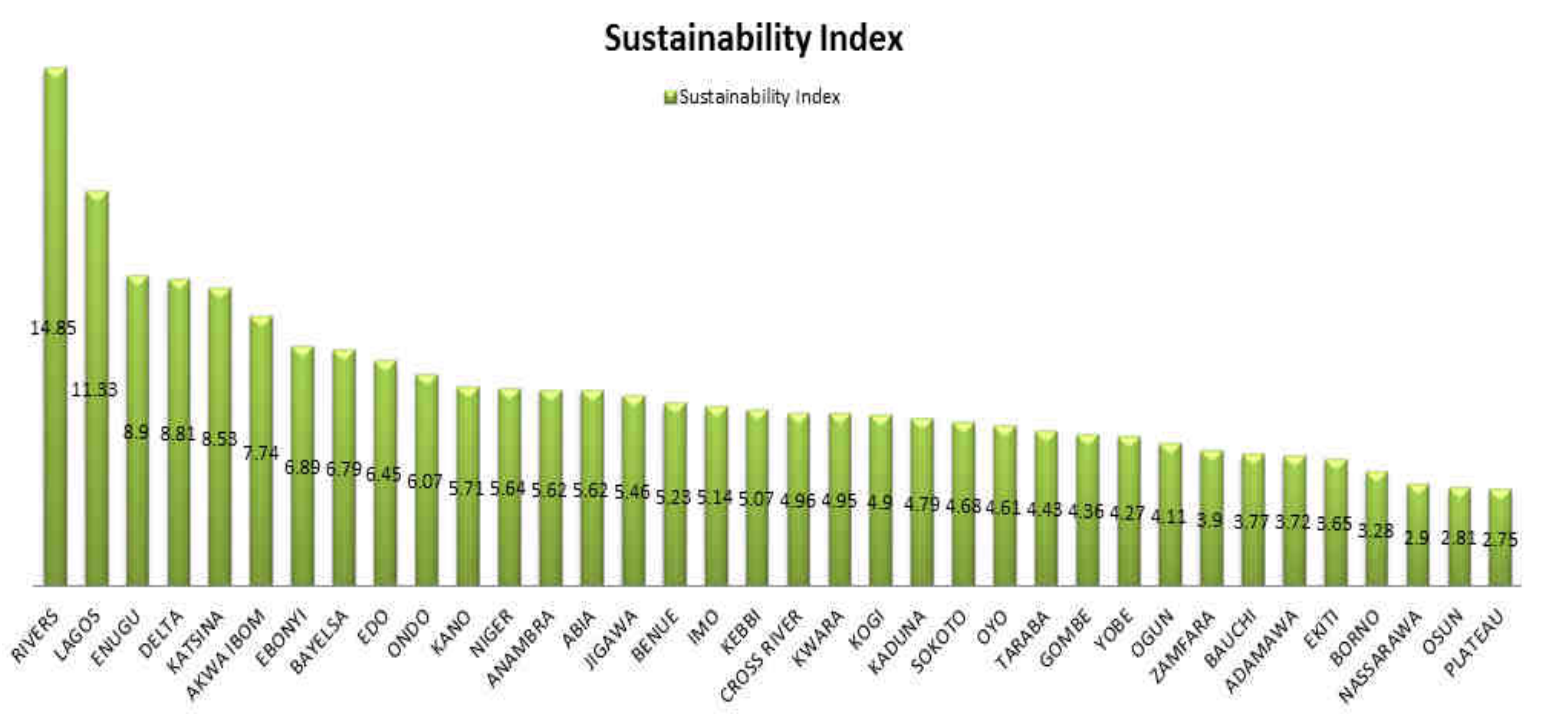

Figure 13: States' Fiscal Sustainability Index

Table 2: Summary of States’ Fiscal Sustainability Index and Release of Bailout Funds

\begin{tabular}{|c|c|c|c|}
\hline States & $\begin{array}{l}\text { Fiscal } \\
\text { Sustainability Index }\end{array}$ & $\begin{array}{l}\text { Bailout Fund Applied } \\
\text { Approved (N'billion) }\end{array}$ & $\begin{array}{l}* \text { Intervention Fund } \\
\text { Released (N'billion) }\end{array}$ \\
\hline RIVERS & 14.85 & 0 & 0 \\
\hline LAGOS & 11.33 & 0 & 0 \\
\hline ENUGU & 8.9 & 4.21 & 4.21 \\
\hline DELTA & 8.81 & 79.84 & 10.94 \\
\hline KATSINA & 8.53 & 3.30 & 11.086 \\
\hline AKWA IBOM & 7.74 & 0 & 0 \\
\hline EBONYI & 6.89 & 4.06 & 8.52 \\
\hline BAYELSA & 6.79 & 1.29 & 0 \\
\hline EDO & 6.45 & 15.07 & 15.58 \\
\hline ONDO & 6.07 & 14.69 & 14.69 \\
\hline KANO & 5.71 & 0 & 20 \\
\hline NIGER & 5.64 & 4.31 & 6.90 \\
\hline ABIA & 5.62 & 14.15 & 14.1 \\
\hline ANAMBRA & 5.62 & 0 & 0 \\
\hline JIGAWA & 5.46 & 0 & 0 \\
\hline
\end{tabular}




\begin{tabular}{|c|c|c|c|}
\hline BENUE & 5.23 & 38.91 & 28.012 \\
\hline IMO & 5.14 & 63.91 & 26.81 \\
\hline KEBBI & 5.07 & 690 & 7.08 \\
\hline CROSS RIVER & 4.96 & 7.86 & 7.86 \\
\hline KWARA & 4.95 & 19.92 & 4.32 \\
\hline KOGI & 4.9 & 51.65 & 0 \\
\hline KADUNA & 4.79 & 0 & 14.30 \\
\hline SOKOTO & 4.68 & 10.09 & 14.093 \\
\hline OYO & 4.61 & 35.71 & 26.61 \\
\hline TARABA & 4.43 & 0 & 9.4 \\
\hline GOMBE & 4.36 & 16.46 & 11 \\
\hline YOBE & 4.27 & 0 & 0 \\
\hline OGUN & 4.11 & 75.40 & 18.92 \\
\hline ZAMFARA & 3.9 & 10.02 & 10.02 \\
\hline BAUCHI & 3.77 & 15.10 & 8.61 \\
\hline ADAMAWA & 3.72 & 2.38 & 9.58 \\
\hline EKITI & 3.65 & 28.40 & 9.6 \\
\hline BORNO & 3.28 & 7.68 & 7.68 \\
\hline NASSARAWA & 2.9 & 8.32 & 8.32 \\
\hline OSUN & 2.81 & 123.59 & 39.98 \\
\hline PLATEAU & 2.75 & 5.36 & 5.36 \\
\hline
\end{tabular}

* Source: Central Bank of Nigeria

From the foregoing, Rivers, Lagos and Enugu headed the sustainability index. This makes them top the list of states performing above average in fiscal sustainability. This makes them capable of handling their fiscal responsibilities during the crisis. This sustainability index as a measure of fiscal performance during the fiscal crisis of 2015 shows the ability of the revenue generated and amount centrally collected to meet up with salary payments and pension arrears. This is done together with a debt-to-revenue ratio for states that opted for increased debt financing during the crisis. However, with a poor economic outlook as a result of the fall in global price of crude oil, revenue from the Excess Crude Account fell and led to increased debt servicing, inability to pay salaries, pensioners and project contractors. From the analysis of the fiscal stance of states above, Borno, Yobe and Osun states performed poorly as indicated by the fiscal sustainability index.

\subsection{Implications of the Bailout}

\subsubsection{Moral Hazard Effect of the Bailout}

There are incentives for every economic activity in a country, and for this particular case of bailout at both 
private and public level are likely to generate socially undesirable incentives. This is because a continuous use of bailout in times of fiscal crisis give agents the opportunity and capability to predict that bailout will always be granted whenever the conditions occur. These expectations for a bailout package could also come with negative or adverse behaviour. Given the prevailing economic structure of a country where market anticipates that illiquid firms or insolvent state governments will get a bailout, it is possible to expect that the existing or even potential creditors will not morally take care of the liquidity of borrowers' assets, leading to recklessness in the way and manner management or state governors handle liquidity issues. In this regard, credit risks are inappropriately handled by recipients of bailout packages.

As a result of this, state governors are encouraged to exercise their revenue and expenditure situations to somewhat reckless manner so as to benefit from a rescue package which may reduce their cost of credit. A simultaneous of many states in a country may lead to the phenomenon of "two-big-to-fail" problem which is the concern here. It is therefore reasonable to deduce that given the large number of states which were affected by non-payment of workers' salaries, retirees' pensions and huge debts (i.e. 28 out of 36 states representing $78 \%$ of the economy), the states may have colluded in deliberately creating the situation, so that they can enjoy the bailout package and a reduced credit cost.

\subsubsection{Bailout and Political Considerations}

It comes with grave concern if the federal government decides to be unfair in issuing bailout to state governments in a fiscal crisis. This is because the federal government has monopoly over funds and thus acts as a lender of last resort to the state governments. The cost of such decisions may vary and could be more than that of the moral hazard on the state and the entire economy. The federal government may also discriminate in the sharing process for political motives. Thus, to either reward loyalty of political affiliation or punish opposition states. As a result, the issue of distributional fairness in the bailout programme is a concern for this study. Figure 15 depicts how the salary intervention fund was allocated to the states given the dominant political party of the states.

STATES' POLITICAL PARTIES AND SALARY INTERVENTION FUND (\#)

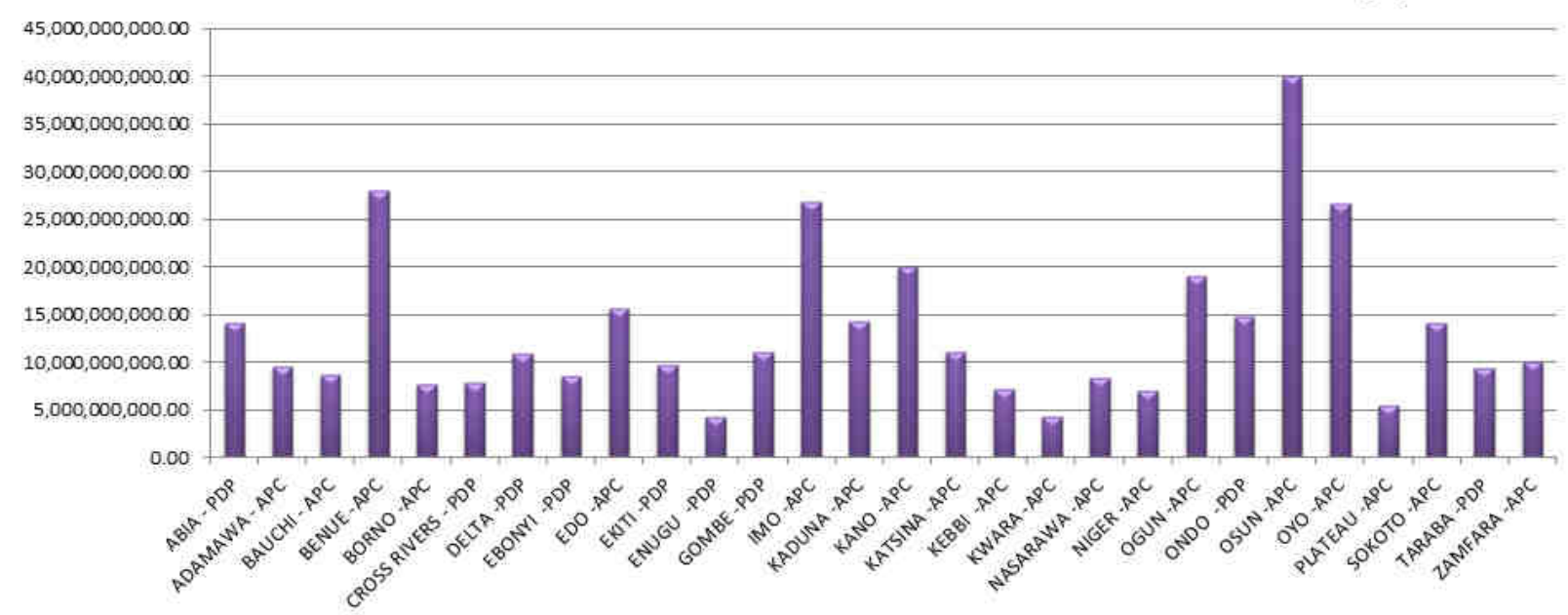

Figure 15: Political Parties of States and the Salary Intervention Fund

From figure 15, states affiliated to the ruling party (APC) received relatively higher amounts than People's Democratic Party (PDP) states. It is important to note also that Bayelsa which is a PDP state, applied but was not given as well as Kogi state which is APC, perhaps they did not meet the conditions. However, Kaduna, Kano and Taraba states did not initially apply but got the salary intervention fund.

\section{Conclusion and Lessons for Policy}

Global events in recent times, particularly the falling crude oil prices which hit a record low of below $\$ 40$ per barrel in 2015, has affected the fiscal operations of many countries. Nigeria’s economy heavily depends on crude 
oil exports, as such adverse effects of the international crude oil market have generated immense crisis where the federal government's revenue transfers to the state and local governments drastically reduced. This created a situation where the lower level governments could not meet their financial obligations even for critical ones like salary payments, pensions and interest payments over a number of months. As a result of the severity of the crisis, on the economy, the federal government consented to the call and rolled out a bailout programme for the states. This study therefore, examined the federal government's bailout programme in tackling the distress situation of the states. The study generally aims at ascertaining the nature and the antecedence of the crisis in respect of fiscal activities of the states. Using qualitative approach and constructing indices of debt sustainability of each state in order to establish their vulnerability conduct the analysis. Graphical trends and tables are used to outline the fiscal performances of the states and the bailout fund distribution of the federal government. The main data for the analysis is obtained from the DMO and the CBN as well as the Central Bureau of Statistics.

The findings indicate that some states were fiscally sustainable as they have internal capacity to generate revenue to meet their financial obligations. In addition, most of the states were found to be negligent in managing their internally generated funds as there are no proper accountability and transparency in the management process. Also, there were clear evidence to support the assertion that the bailout fund was allocated to the incumbent governments' politically aligned states, as the majority of states which received the salary intervention fund were APC dominated states. It is however, critical to note that the bailout programme is not sustainable and not a prudent economic policy, particularly for Nigeria because it has the tendency to cause the states' efforts at mobilizing internally generated funds to reduce. The bailout in the form of loan restructuring of the states' indebtedness to the banks helped to strengthen the financial standings of the lending institutions. However, states considered the gesture as an incentive to continue borrowing and they do this without any regards for the risk involved.

In view of the above, the study provides the following lessons for policy:

(i) bailout funds should be given only when there is systemic fiscal crisis where a particular state cannot access credit from anywhere and in any form. This would go a long way to reduce future recklessness on the part of the states.

(ii) Bailout funds should go together with "haircuts" whereby higher interest rates and other charges are imposed on the states as punitive measures to secure the creditors (banks) and the tax payers (Nigerians). This should discourage state governments from engaging in high risk financial transactions.

(iii) Federal government should desist from political considerations in allocating bailout funds and any other common national resource and allow the principles of equity and efficiency to guide the distribution. To achieve this, an independent committee should be constituted to undertake the allocation.

(iv) State governments should be encouraged to increase their Internally Generated Revenue (IGR) and reduce their dependence on the allocations from the Federal government. This could be achieved through effective local tax administration by state and local governments and building the technical capacity of the personnel in internal tax revenue mobilisation as well as enhancing the tax bases of the affected states.

(v) Additionally, the study proposes a controlled expenditure by the states so as to close the deficit gaps that has become a common feature in fiscal operations of the states. In this regard, recurrent expenditure should be reduced while capital expenditure on ventures that would yield infrastructural transformation should be encouraged.

\section{References}

Allers, M. (2015), "The Dutch local government bailout puzzle”, Public Administration, Vol. 93 No.2, pp. 451470.

Cheryl D. B. (1992), Overt and Covert Bailouts: Developing a Public Bailout Policy. Indiana Law Journal, Vol. 951, 956-58.

Conceptualization of Bailout. Available at www.afarber.com/definition-of-bailout Retrieved on $20^{\text {th }}$ March 2016

Dodd-Frank Wall Street Reform and Consumer Protection Act, Public Law No. 111-203, 124 Stat. 1376 (2010)

(codified as amended in scattered sections of 7, 12, and 15 United States Constitution). 
GTBank (2016). "Macro-Economic and banking sector themes for 2016", Available at http://www.finance.gov.ng/index.php/resources/224-budget-2016

Oates, W.E. (1999), “An Essay on Fiscal federalism”, Journal of economic Literature, Vol. 37 No. 3 pp. 1120 1149.

Philip C. \& Dozie O. (2010), 'State Bailouts in an Era of Financial Crisis: Lessons from Africa' GTA Analytical Paper No.5. World Bank Global Trade Alert

Richard A.M. (1959). The Theory of Public Finance. A study in Public Economy. New York:

McGraw-Hill.

Vincent N. \& Wilson E.H. (2013), 'Fiscal Responsibility Law, Fiscal Discipline and Macroeconomic Stability: Lessons from Brazil and Nigeria' International Journal of Economics and Management Sciences Vol. 2, No. 06, pp. 01-10. 